\title{
Towards a Measure of Multidimensional Poverty in COVID-19 Time in Senegal: Identification of Risk Factors and Vulnerable People
}

\author{
Muhammad Ba \\ Economics, and Management Department, Gaston Berger University, Saint-Louis, Senegal \\ Email:ba.muhammad@ugb.edu.sn
}

How to cite this paper: Ba, M. (2020). Towards a Measure of Multidimensional Poverty in COVID-19 Time in Senegal: Identification of Risk Factors and Vulnerable People. Open Journal of Social Sciences, 8 , 267-285.

https://doi.org/10.4236/jss.2020.87022

Received: June 24, 2020

Accepted: July 24, 2020

Published: July 27, 2020

Copyright (อ 2020 by author(s) and Scientific Research Publishing Inc. This work is licensed under the Creative Commons Attribution International License (CC BY 4.0).

http://creativecommons.org/licenses/by/4.0/ (c) (i) Open Access

\begin{abstract}
The objective of this paper is to design a multidimensional poverty index, based on the Alkire-Foster (AF) method, to identify people vulnerable to COVID-19 and risk factors. The use of the Demographic and Health Survey (DHS) dataset has led to the choice of the following dimensions: Education, Hygiene, Staying at home, Physical distance, and recovery capacity. Each dimension is composed of indicators found in the global multidimensional poverty index. The findings show that $61.4 \%$ of Senegalese are vulnerable to COVID-19 because they suffer deprivation in at least a third of the indicators. Also, among the vulnerable $47.05 \%$ are poor according to the wealth index. The deprivation in electricity, housing, sanitation, and cooking fuel are the most important risk factors in the Senegalese context. The regions located in the South and East are those where the populations are more vulnerable. However, the number of confirmed cases is higher in the northern and western regions where there are fewer vulnerable people. In these regions, the greatest risk factor is promiscuity. Difficulty in observing physical and social distance and having a suitable living environment are major factors of vulnerability to emerging infectious diseases such as COVID-19 in a developing country like Senegal.
\end{abstract}

\section{Keywords}

Multidimensional Poverty, COVID-19, Vulnerable People, Risk Factors, Senegal

\section{Introduction}

The emergence of the SARS-CoV-2 virus, the etiological agent of COVID-19, 
has led the world into an unprecedented health emergency with thousands of people infected in almost every country in the world. The virus is transmitted mainly through respiratory droplets and contact routes from contaminated items/ surfaces (Rothan \& Byrareddy, 2020). According to the World Health Organisation (WHO), in the absence of a vaccine and effective treatment, many countries around the world have opted for preventive measures: lockdown; physical distancing, frequent hand washing, etc. (WHO, 2020).

However, in developing countries, the adoption of such measures is challenging for populations. According to (Buheji et al., 2020), it is difficult for the poor to adhere to restrictive measures of social isolation or lockdown. Moreover, the history of epidemics such as SARS and Ebola has shown that income poverty is an important factor in disease transmission (Abramowitz et al., 2015; Bucchianeri, 2010). Thus, being poor may increase the risk of being infected with COVID19; just as being infected increases the risk of falling into poverty (Diwakar, 2020). Beyond these conclusions based on the monetary approach to poverty, multidimensional measures can also provide more accurate information on the inability of the poor to monitor health measures or their degree of vulnerability to a contagious disease such as COVID-19. People suffering from multidimensional poverty are deprived of real opportunities or capabilities (Sen, 1985, 2000). In times of the COVID-19 outbreak, their multiple deprivations make them vulnerable and unable to adopt preventive measures. Thus, this paper seeks to construct a multidimensional poverty index that answers following question: how and to what extent people in Senegal are deprived in living standard indicators directly related to the ability to prevent and cure COVID-19?

In recent years, the multidimensional approach to poverty has received favorable attention in the research and policy community. Poverty is accepted as a multi-dimensional phenomenon that will need to be assessed by going beyond income or consumption expenditure alone. Amartya Sen's work on poverty (Sen, 1976) and the capability approach (Sen, 1980, 2000, 2009) have contributed significantly to the development of literature on the multidimensional and nonmonetary measurement of poverty. Several approaches to multidimensional poverty measurement exist. For example, the dominance approach (Bourguignon \& Chakravarty, 2008; Duclos et al., 2006); Fuzzy set poverty approach (Cheli \& Lemmi, 1995; Chiappero Martinetti, 2000) and statistical techniques (Krishnakumar \& Ballon, 2008; Maggino \& Zumbo, 2012; Nardo et al., 2005). There is also the axiomatic approach that respects the two steps of poverty measurement proposed by (Sen, 1976): identification and aggregation. It is within this family of multidimensional measures of poverty that the Alkire-Foster (AF) method (Alkire \& Foster, 2007, 2011) belongs. The particularity of the AF method is that it is based on a "double-cut-off" method (Chen \& Chang, 2019). The first is used to determine whether or not an individual is poor in a dimension. The second uses whether an individual is multidimensionally poor or not.

Thus, (Alkire et al., 2020), using the components of the global multidimensional poverty index estimated that a lack of access to clean drinking water, un- 
dernutrition, and no clean cooking fuel put people at a high risk to COVID-19. They found that in sub-Saharan Africa 216 million people are multidimensionally poor and are associated with a higher level of risk exposure to the COVID-19 because they suffer from deprivation, simultaneously for all the three risk factors cited above. These three factors are indicators and not dimensions. (Tavares \& Betti, 2020) drawing from Brazilian data, identified four dimensions in which they rank the few indicators of the global MPI. These dimensions are related to hygiene, staying at home, physical distance, and recovery capacity. They mainly found that $39.1 \%$ of the population is deprived in sanitation; $30 \%$ may have inadequate access to safe drinking water; $21.9 \%$ may have indoor pollution; and $12.7 \%$ live in an overcrowd house. They conclude that people having acute multidimensional poverty are more exposed to the virus. To our knowledge, apart from these two studies, there is still little research on the implications of multidimensional poverty on prevention and cure at COVID-19.

Although the analysis of (Alkire et al., 2020) is based on a few indicators, they argue that the global MPI database provides a widely used source of information that can be employed for immediate COVID-19 responses such as regional targeting. Therefore, this paper seeks to complement this literature by using the AF method in the Senegalese context for multidimensional poverty measurement to identify the most vulnerable people to the contagion of COVID-19 and the risk factors beyond those identified by Alkire et al. (2020). Thus by constructing a multidimensional measure of poverty in the context of COVID-19, this paper also contributes to the literature on the measurement of multidimensional poverty using the AF method in Senegal. To our knowledge, apart from the annual measurements of the OPHI, this paper is the first to propose a multidimensional evaluation of poverty in Senegal based on the axiomatic method of AF. The main reason for this study is that to set up effective strategies to control COVID-19 in Africa, it is necessary to know which populations are vulnerable and which dimensions whose deprivation accentuates the risk of contamination. In an African country, such as Senegal, using a multidimensional poverty index constructed from the dimensions necessary to cope with infectious diseases is relevant to link the fight against poverty and the objective of health for all.

The remainder of this paper is structured as follows. A second section presenting the background by describing, on the one hand; the evolution of COVID-19 in Senegal and the poverty situation, on the other hand. A third section presents the data, the AF counting method, and the specification of dimensions and indicators. A fourth section presents findings stemming from the AF method application to Senegalese data. A fifth section discusses findings and concludes.

\section{Background}

\subsection{COVID-19 Trends in Senegal}

The first case tested positive for COVID-19 in Senegal dates back to March $3^{\text {rd }}$, 2020. Three months later, several thousand people tested positive for the virus in 
Senegal. In Africa. although the rate of progression is less significant than in comparator countries such as Algeria, Morocco, Nigeria, Cote d'Ivoire, South Africa, and Morocco (Figure 1), Senegal shows an increase in the rate of spread that does not weaken unlike other countries (Figure 2).

According to the Senegalese Ministry of Health, on 18th June 2020, 5888 people tested positive for COVID-19, 84 of whom died, i.e. a lethality of $1.4 \%$. These patients were registered in 54 health districts, i.e. a proportion of $68 \%$

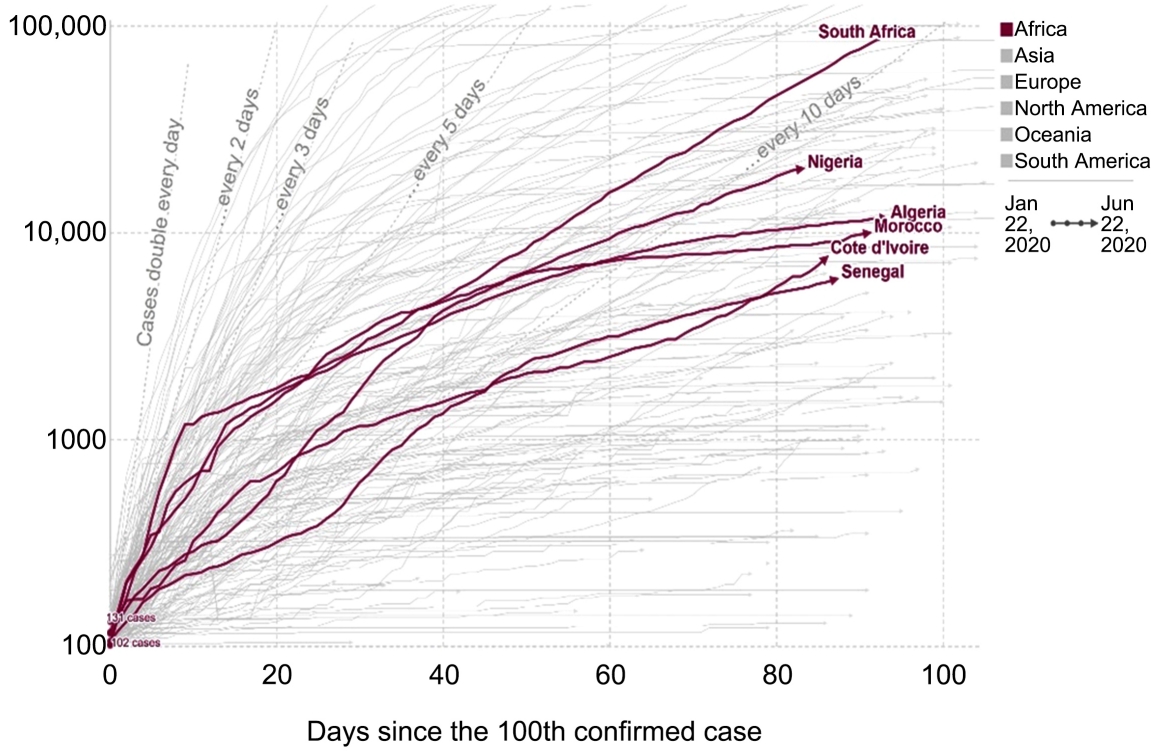

Source: European CDC - Situation Update Worldwide - Last updated 22nd June, 11:00 (London time)

OurWorldInData.org/coronavirus · CC BY

Figure 1. Total Confirmed COVID-19 cases: how rapidly are they increasing in Senegal. South Africa. Algeria. Nigeria. and Cote d'Ivoire?

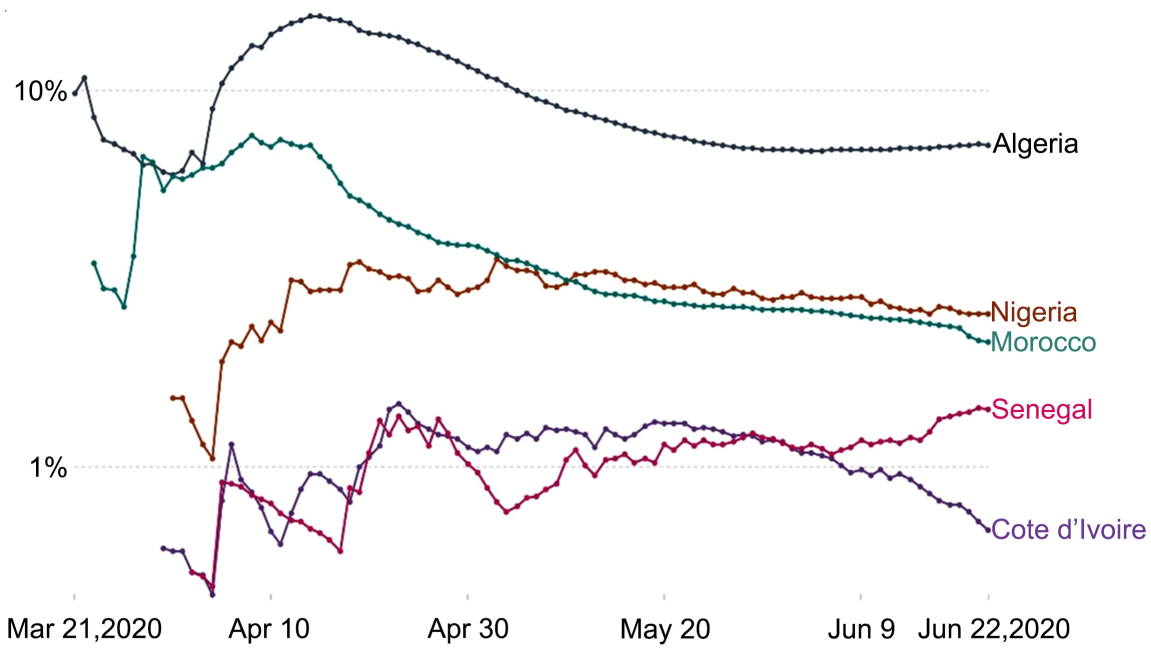

Source: European CDC - Situation Update Worldwide - Last updated 3rd June, $\quad$ CC BY 11:00 (London time) - Data last updated 22nd Jun, 12:03 (GMT+02:00)

Figure 2. Cases fatality rate on the ongoing COVID-19 pandemic in Senegal, South Africa, Algeria, Nigeria, and Cote d'Ivoire? 
(54/79). According to geographical distribution, Dakar is the epicenter of the epidemic in Senegal, accounting for more than $73 \%$ of infected cases. It is followed by the region of Diourbel with the religious city of Touba as a second epicenter of the virus. According to data from the Senegalese Ministry of Health, the majority of infected persons are men (56.68\% versus $43.32 \%$ women). For both sexes, the majority of infected persons are between 20 and 39 years of age.

\subsection{Poverty in Senegal}

Senegal is a country where more than a third of its population lives below the absolute poverty line. This poverty rate may be higher when other types of measures are considered (Figure 3). For example, with a US $\$ 3.10$ threshold, the poverty rate doubles from its absolute level (\$US 1.90). Relative poverty defined about the cost of the food basket needed to have the required caloric intake, it indicates that $47 \%$ of the population does not have access to it (ANSD, 2013). The feeling of being poor is experienced by more than half of the population. i.e. 58.8\% (ANSD, 2015).

Multidimensional poverty calculated with 2017 DHS-7 data by the Oxford Poverty Human Initiative (OPHI). With a multidimensional poverty cut-off of 0.33 , more than $53 \%$ suffer at least 3 deprivations in 10 of the indicators used to calculate the MPI (OPHI, 2019). Multidimensional poverty is more accentuated in rural areas than in urban areas (77.7\% versus $22.7 \%)$ (Figure 4). The regions most affected by this form of poverty are Kaffrine, Kolda, Tambacounda, Kedougou, Sedhiou and Diourbel (OPHI, 2019).

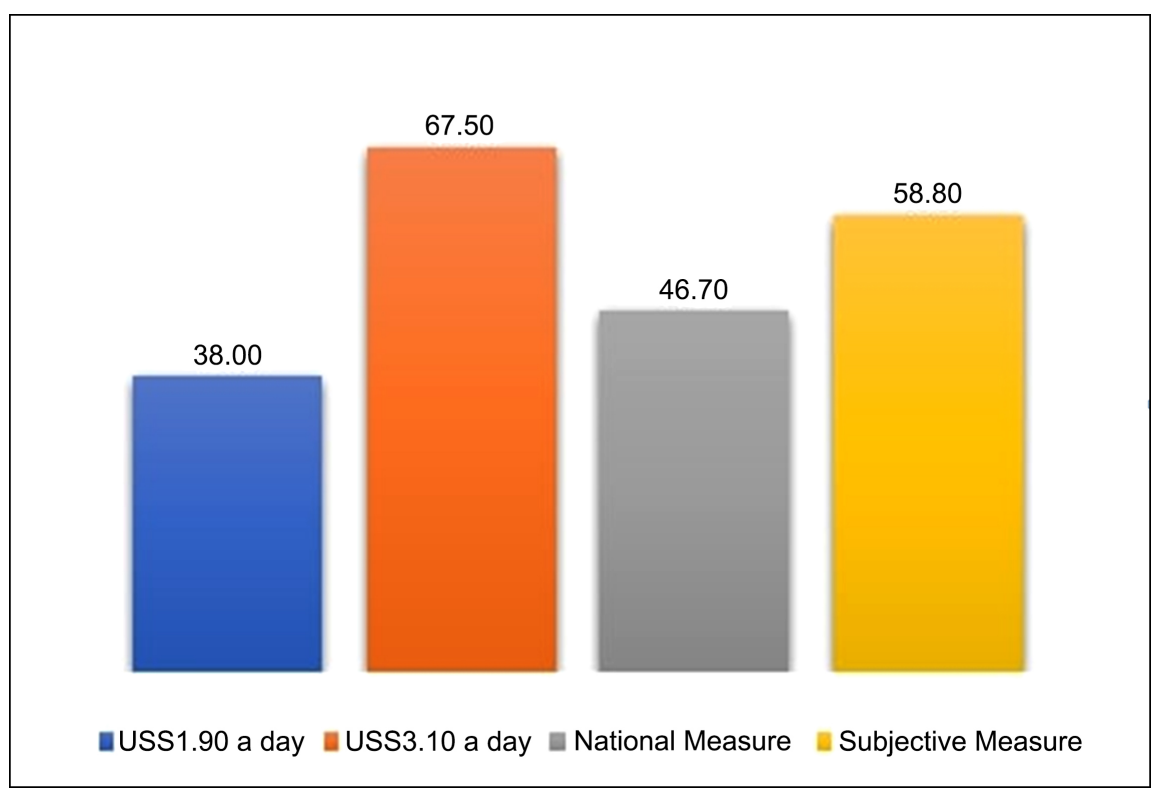

Figure 3. Headcount ratio by poverty measure. Source: Monetary poverty measures are the most recent estimates from the World Bank (Azevedo, 2011). Monetary poverty measure refers to 2011 (\$1.90 a day). 2011 (\$3.10 a day) and 2011 (national measure). Subjective measure refers to 2014 (ANSD). 


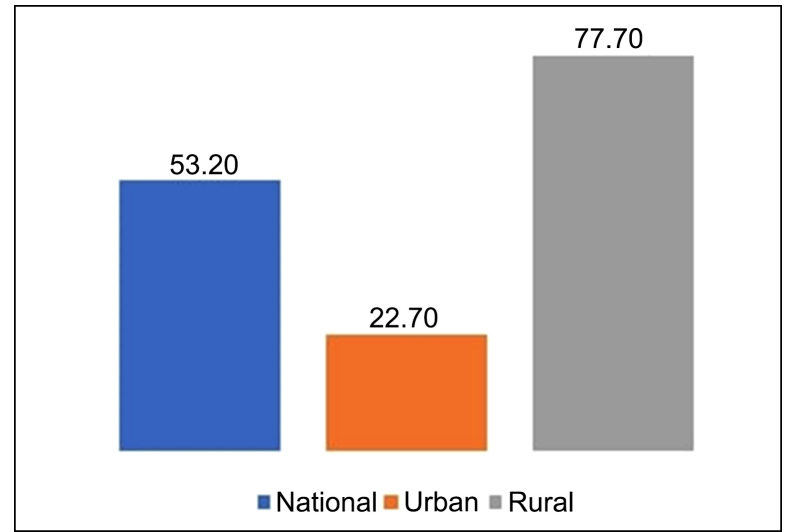

Figure 4. Headcount ratio multidimensional poverty national et by area. Source: Author from Global MPI Country Briefing 2019: Senegal (Sub-Saharan Africa).

\section{Data and Measures}

\subsection{Source of Data}

The data used in this paper is drawn from the last demographic and health survey (DHS-7) in Senegal. DHS surveys collect a set of information on a wide range of topics from a representative sample of the population in the countries participating in the DHS Program (Croft et al., 2018). The data collected in 2017 are the latest available and accessible data with information on household living conditions. The accessibility and availability of these data prompted OPHI to use them to calculate the global multidimensional poverty index. All DHS surveys generally use questionnaires that provide information on the household, adult household members, and children. Eligible household members are typically children under age 5, women, and men which ages are ranged between $15-49$ (Croft et al., 2018).

In Senegal, the 2017 Continuous DHS aimed to produce results that were representative at the national level, of urban and rural areas and Senegal's 14 administrative regions. Thus, with a stratified sample draw by stratum, a total of 8800 households were selected (4092 in urban areas and 4708 in rural areas). In each household, all women aged 15 - 49 years are eligible for the survey, as well as children under 5 years of age. Also, in a sub-sample of every second household, all men aged 15 - 59 were eligible to be surveyed. The following Table 1 summarizes the different information on the results of the household and individual interviews excluding children under 5 and adolescents under 15. After removing non-national individuals found in households in the survey, we used an unweighted sample of 74,444 individuals.

\subsection{AF Method}

Sen (1976) identified two steps for measuring any multidimensional poverty: identification and aggregation and the A-F method is not spared. Table 2 summarizes the different parts of these two steps described by Alkire et al. (2015). 
Table 1. Household size, number of interviews and response rate by place of residence (unweighted), EDS Continue Senegal 2017.

\begin{tabular}{cccc}
\hline Results & Urban & Rural & Total \\
\hline Household Interviews & & & 8800 \\
Selected households & 4092 & 4708 & 8522 \\
Occupied households & 3931 & 4591 & 8380 \\
Households interviewed & 3839 & 4541 & 98.3 \\
Household response rate (\%) & 97.7 & 98.9 & 98.3 \\
\hline
\end{tabular}

Source: (ANSD \& ICF, 2018).

Table 2. Summary of the different steps of the AF method.

\begin{tabular}{|c|c|c|c|}
\hline Step & Definitions & Notations and equations & \\
\hline \multirow{6}{*}{ Identification } & $\begin{array}{l}\text { Defining the set of indicators which will be considered in the } \\
\text { multidimensional poverty measure. }\end{array}$ & $\begin{array}{l}x_{i j} \text {. is the achievement of person } \\
i \text { in dimension } j\end{array}$ & \\
\hline & $\begin{array}{l}\text { Setting the level of achievement considered sufficient to be } \\
\text { considered as non-deprived in each indicator using the } \\
\text { deprivation cutoff points }(z)\end{array}$ & $\left(z_{1} \cdots z_{d}\right)$ & \\
\hline & $\begin{array}{l}\text { Applying the cutoff points to ascertain whether each person is } \\
\text { deprived or not in each indicator }\left(g^{0}\right)\end{array}$ & $g_{i j}^{0}= \begin{cases}1 & x_{i j}<z_{j} \\
0 & x_{i j} \geq z_{j}\end{cases}$ & (1) \\
\hline & $\begin{array}{l}\text { Selecting for each indicator the relative weight or value }(w) \text {. } \\
\text { The sum of the relative weight is equal to one. }\end{array}$ & $\left(w_{1} \cdots w_{d}\right)$ & \\
\hline & $\begin{array}{c}\text { Computing "deprivation score" which is the weighted sum } \\
\text { of deprivations for each person. }\end{array}$ & $c_{i j}=\sum_{j=1}^{d} w_{j} g_{i j}^{0}$ & (2) \\
\hline & $\begin{array}{l}\text { Determining (normatively) the proportion of weighted deprivations a } \\
\text { person needs to experience to be considered multidimensionally poor. } \\
\text { The poverty cutoff point } k \text { and } \rho_{k}\left(x_{i} ; z\right) \text { identification function which } \\
\text { identifies each person as multidimensionally poor or not } \\
\text { according to the selected poverty cutoff point } k \text {. }\end{array}$ & $\rho_{k}\left(x_{i} ; z\right)=\left\{\begin{array}{cc}1 & c_{i}>k \\
0 & \text { otherwise }\end{array}\right.$ & (3) \\
\hline \multirow{3}{*}{ Aggregation } & $\begin{array}{c}\text { Censoring deprivations of the non-poor and computing the } \\
\text { proportion of people who have been identified as multidimensionally } \\
\text { poor }(q) \text { in the population }(n) \text {. It's also called Headcount } \\
\text { Ratio and noted: } H\end{array}$ & $H=\frac{q}{n}$ & (4) \\
\hline & $\begin{array}{l}\text { Computing the average share of weighted indicators } \\
\text { in which poor people are deprived }(A) \text {. }\end{array}$ & $A=\sum_{i=1}^{q} \frac{c_{i}(k)}{q}$ & (5) \\
\hline & $\begin{array}{l}\text { Computing the } M_{0} \text { measure as the association of the headcount } \\
\text { ratio }(H) \text { and the average share of weighted indicators }(A) \text {. }\end{array}$ & $M_{0}=H * A$ & (6) \\
\hline
\end{tabular}

Source: Author. 
Thus, the AF method uses the censored achievement approach, more precisely the counting approach which identifies a person as poor according to the number of deprivations he or she experiences in the different dimensions considered. Unlike other multidimensional measurement approaches, the AF method uses a dual cut-off point to identify the poor. For the aggregation step, the AF methodology relies on an extension of the unidimensional Foster-Greer-Thorbeck (FGT) poverty measures of (Foster et al., 1984) which are useful for overcoming the limitations of headcount ratio $(\mathrm{H})$. Indeed, $M_{0}(X \cdot z)$ is an adjusted headcount ratio and satisfies a set of properties such as dimensional monotonicity and subgroup decomposability (Alkire et al., 2015). The aggregation step is written in equation (6) can be rewritten as follows.

$$
\begin{aligned}
M_{0}(X \cdot z) & =\mu(c(k))=H^{*} A=\frac{q}{n} * \frac{1}{q} \sum_{i=1}^{q} c_{i}(k) \\
& =\frac{1}{n} \sum_{i=1}^{n} c_{i}(k)=\frac{1}{n} \sum_{i=1}^{n} \sum_{j=1}^{d} w_{j} g_{i j}^{0}(k)
\end{aligned}
$$

With the cardinal data, the AF class measure can be completed by calculating $M_{1}$ and $M_{2} . M_{1}$ is the Adjusted Poverty Gap and refers to the average weighted deprivation gap experienced by the poor out of the total number of deprivations this society could experience (Alkire et al., 2015). $M_{2}$ is the Adjusted Squared Poverty Gap Measure and reports the average weighted squared gap or poverty severity experienced by the poor out of the total deprivations this society could experience (Alkire et al., 2015). Among these three class measures, $M_{0}$ is the only one that can be implemented with ordinal data. In this paper, we are only interested in $M_{0}$ because the data used are ordinal.

\subsection{Dimensions, Indicators, and Weight}

According to (Krishnakumar, 2014), the choice of dimension and their indicators may be based on theoretical foundations or philosophical and on practical or statistical considerations. In this paper, the choice of dimensions is made based on the achievements that make it possible to comply with health measures and the availability of data. The use of the DHS dataset has led to the choice of indicators that can be placed in the same dimensions as those selected by ( $\mathrm{Ta}$ vares \& Betti, 2020): hygiene, staying at home, physical distance, and recovery capacity. In addition to these dimensions, education is selected to determine whether deprivation in this dimension is a risk factor in the Senegalese context. The choice of each dimension is justified in terms of judging its relevance in building a person's resilience against the virus.

The first dimension, Education, is measured by a single indicator that is derived from the OPHI's global multidimensional poverty index and it's related to the number of years spent in school. We assumed that not having a minimum level of education could lead to difficulties in complying with health measures.

The second dimension, Hygiene; access to safe water and sanitation are the two indicators drawn from the MPI. According to WHO (2018b), a significant 
number of diseases could be prevented through access to a safe water supply, adequate sanitation services; and better hygiene practices. Access to safe water is essential for preventing COVID-19 through hand washing. Moreover, drinking unsafe water increasingly weakens the immune system (WHO, 2019) ${ }^{1}$.

The third dimension is "Staying at home". Incentive measures to stay at home is recognized as a way of reducing the risk of contracting a disease if it is carried out. Besides, it appears that staying at home can be challenging if housing is made of inadequate materials or if there are not the basic elements that provide a minimum of comfort. Based on the choices of (Tavares \& Betti, 2020); access to electricity; and the housing environment are chosen as the two indicators of this dimension.

Physical distance is the fourth dimension that provides information about the ability to live in an environment that reduces the spread risk of the virus. According to Hunt et al. $(2020)^{2}$, the deprivation in this dimension increasing the risk to contract COVID-19 disease. This dimension is measured by two indicators: "overcrowded housing" and "dependency ratio".

The last dimension refers to the strength of the immune system. which means that in the event of illness, the person is prepared to quickly recover. The two indicators that are considered as risk factors by (Alkire et al., 2020) are included in this paper for this dimension: cooking fuel and nutrition. Inadequate cooking fuel is associated with indoor pollution that harms respiratory systems (WHO, 2018a). Nutritional deprivation is a risk factor for infectious diseases including COVID-19 and exacerbates immune system deficiency (Alkire et al., 2020).

Weighting in the construction of a multidimensional index provides information on the value of indicators and dimensions. The decision on the weight to be assigned to each indicator is part of the value judgments that the researcher makes based on the purpose of using the A-F method. In this paper, indicator weights are extracted from the results of a Principal Component Analysis (PCA) presented which calculates the weights using the data structure. PCA is largely used in the compilation of indices composites due to its objective allocation of the weightings. However, to test the robustness of our choice, we compared the outcome of the multidimensional poverty index with different weighting structures (equal weighting. subjective weighting (expert opinion)). The results presented in the Appendix show a non-significant difference between the weighting systems regardless of the deprivation threshold selected. The weights assigned to each indicator are presented in the Table 3.

\section{Results}

In this paper, the deprivation cut-off is set at a value of 0.33 , as OPHI's MPI.

${ }^{1}$ WHO (2019). Drinking Water. World Health Organization, 14 June 2019, (https://www.who.int/en/news-room/fact-sheets/detail/drinking-water)

${ }^{2}$ https://www.individualdeprivationmeasure.org/wp-content/uploads/Poverty-and-Vulnerability-toCOVID-19-in-South-Africa_IDM_Briefing-Paper.pdf 
Table 3. Specification of thresholds and weight indicators.

\begin{tabular}{|c|c|c|c|}
\hline Dimensions & Indicators & Thresholds (deprivation definitions) & Weight \\
\hline Education & Education & $\begin{array}{l}\text { The entire household is considered deprived if no } \\
\text { household member aged } 10 \text { years or older has } \\
\text { completed } 6 \text { years of schooling. }\end{array}$ & 0.08 \\
\hline \multirow{2}{*}{ Hygiene } & $\begin{array}{c}\text { Drinking } \\
\text { water }\end{array}$ & $\begin{array}{l}\text { Members of the household are considered deprived } \\
\text { if the household does not have access to improved } \\
\text { drinking water (according to the SDG guidelines) } \\
\text { or safe drinking water is at least a } 30 \text {-minute } \\
\text { walk from home roundtrip. }\end{array}$ & 0.18 \\
\hline & Sanitation & $\begin{array}{l}\text { Members of the household are considered deprived if } \\
\text { the household's sanitation facility is not improved or } \\
\text { it is improved but shared with other households. }\end{array}$ & 0.16 \\
\hline \multirow{2}{*}{$\begin{array}{l}\text { Staying at } \\
\text { home }\end{array}$} & Housing & $\begin{array}{l}\text { Members of the household are considered deprived } \\
\text { if the household has dirt. sand or dung floor }\end{array}$ & 0.14 \\
\hline & Electricity & The household does not have access to electricity & 0.1 \\
\hline \multirow{2}{*}{$\begin{array}{l}\text { Physical } \\
\text { distance }\end{array}$} & $\begin{array}{l}\text { Promiscuity } \\
\text { ratio }\end{array}$ & $\begin{array}{c}\text { Members of a household are deprived of physical } \\
\text { distance if the number of persons per room is } \\
\text { more than } 3\end{array}$ & 0.08 \\
\hline & $\begin{array}{l}\text { Dependency } \\
\text { ratio }\end{array}$ & $\begin{array}{l}\text { The household has three or more non-working-age } \\
\text { per working-age residents. }\end{array}$ & 0.05 \\
\hline \multirow[b]{2}{*}{$\begin{array}{l}\text { Capacity } \\
\text { recovery }\end{array}$} & Cooking fuel & $\begin{array}{c}\text { Members of the household are considered deprived if } \\
\text { the household uses solid fuels and solid biomass fuels } \\
\text { for cooking (wood. animal dung. crop wastes. } \\
\text { and charcoal...). }\end{array}$ & 0.12 \\
\hline & Nutrition & $\begin{array}{l}\text { Members of the household are considered deprived if the } \\
\text { household has a child under } 5 \text { whose height-for-age or } \\
\text { weight-for-age is under two standard deviation below } \\
\text { the median. or has a teenager with BMI-for-age that is } \\
\text { under two standard deviation below the median. or has } \\
\text { adults with BMI threshold that is below } 18.5 \mathrm{~kg} / \mathrm{m}^{2} \text {. }\end{array}$ & 0.09 \\
\hline Total of weight & & & 1 \\
\hline
\end{tabular}

Source: Author drawing from Tavarrez and Betti (2020) and Alkire et al. (2020). Computation of indicator weights by the author.

Drawing from the results of an estimation of the incidence evolution $(\mathrm{H})$ and the adjusted headcount ratio $\left(M_{0}\right)$, we observed that; above $\mathrm{k}=3$, their values significantly decrease from one cut-off point to another (Figure 5). Thus, we considered that an individual is multidimensional poor if he or she is deprived of at least three of the nine indicators. Besides, we considered that people who are deprived in at least two-thirds of the indicators are suffering from severe poverty. Economic poverty measured by the wealth index is particularly valuable when data on income and expenditures are not available to measure household economics status (Chakraborty et al., 2016). 


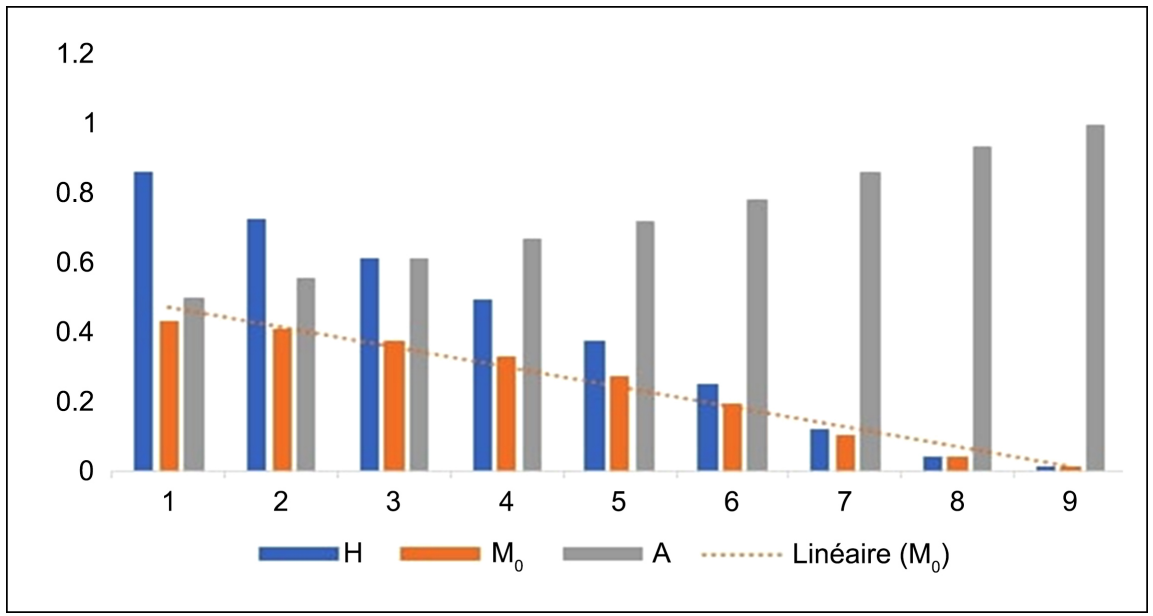

Figure 5. Evolution of different key indices for different cut-off points (k). Source: DHS-7. Senegal. Calculated and elaborated by the author.

The findings show that $61.4 \%$ of Senegalese are vulnerable to COVID-19. The intensity of vulnerability reflects that individuals are deprived in at least twothirds of the indicators $(\mathrm{A})$ and the adjusted headcount ratio index $\left(M_{0}\right)$ is 0.37 . Among the vulnerable $47.05 \%$ are poor according to the wealth index. The population severely vulnerable accounts for $25.2 \%$ and is almost all of them are identified as poor (Table 4).

The contribution of the indicators in the calculation of the adjusted headcount ratio $\left(M_{0}\right)$ shows that deprivation in electricity, housing, sanitation, and cooking fuel are the most important risk factors in the Senegalese context. Safe water is a secondary factor in the same way as education, and dependence ratio (Table 5). This can be explained by the fact that the deprivation rates for these indicators are relatively low (see annex).

Analysis following the multidimensional deprivation index decomposition by region reveals that the regions where populations are more vulnerable to COVID19 are: Tambacounda, Kolda, Kaffrine, and Sedhiou. These regions are also those where poverty, according to the wealth index, is higher. The contributing factors to this deprivation of capacity are located in these regions relative to the "staying at home" dimension: electricity and housing. The regions located in the West and North West (Dakar,Thiès, and Saint-Louis) are those where households are least vulnerable to COVID-19. However, in these regions, promiscuity deprivation is an important risk factor due to its higher contribution than the national average in each of its regions and especially in Dakar. Regarding the contribution of the indicators by region, it appears that in almost all regions, "sanitation" is an important factor of vulnerability to an infectious disease such as COVID19. For this indicator too, the results show that it is an important risk factor for the inhabitants of Dakar (Table 6).

As shown in figure below several regions of Senegal are at high risk of spreading the virus (Figure 6). The western, central-western and northern regions are less vulnerable than those in the south and south-east. However, the current situation 
Table 4. Vulnerability to COVID-19 and poverty.

\begin{tabular}{|c|c|c|c|c|c|}
\hline & Vulnerable & $\begin{array}{c}\text { At Severe } \\
\text { Vulnerability }\end{array}$ & Poor & $\begin{array}{l}\text { Vulnerable } \\
\text { and Poor }\end{array}$ & $\begin{array}{c}\text { At Severe } \\
\text { vulnerability and poor }\end{array}$ \\
\hline$H$ (\%-headcount ratio) & $61.4 \%$ & $25.2 \%$ & $50.43 \%$ & $47.05 \%$ & $24.17 \%$ \\
\hline$M_{0}$ (Adjusted headcount ratio) & 0.377 & & & & \\
\hline A (Intesity of vulnerability) & 0.615 & & & & \\
\hline
\end{tabular}

Source: DHS-7. Senegal. Calculated and elaborated by the author.

Table 5. Identification of risk factors.

\begin{tabular}{|c|c|c|c|c|c|c|c|c|c|}
\hline & \multicolumn{4}{|c|}{ Important factors } & \multicolumn{4}{|c|}{ Second factors } & \multirow{2}{*}{$\begin{array}{c}\text { Third factor } \\
\text { Nutrition }\end{array}$} \\
\hline & Electricity & Housing & Sanitation & $\begin{array}{l}\text { Cooking } \\
\text { fuel }\end{array}$ & Promiscuity & Education & Water & $\begin{array}{c}\text { Dependence } \\
\text { ratio }\end{array}$ & \\
\hline Contribution to $M_{0}$ & 0.218 & 0.178 & 0.144 & 0.123 & 0.092 & 0.07 & 0.067 & 0.065 & 0.044 \\
\hline
\end{tabular}

Source: DHS-7. Senegal. Calculated and elaborated by the author.

Table 6. Vulnerability to COVID-19 and risk factors by region.

\begin{tabular}{|c|c|c|c|c|c|c|c|c|c|c|c|c|}
\hline \multirow[b]{2}{*}{ Regions } & \multirow[b]{2}{*}{ Poor } & \multirow[b]{2}{*}{$\mathrm{H}$} & \multirow[b]{2}{*}{$M_{0}$} & \multicolumn{9}{|c|}{ Contributions of indicators } \\
\hline & & & & Education & Electricity & Housing & Promiscuty & $\begin{array}{c}\text { Dependence } \\
\text { ratio }\end{array}$ & $\begin{array}{l}\text { Cooking } \\
\text { fuel }\end{array}$ & Nutrition & Sanitation & Water \\
\hline Dakar & 0.02 & 0.132 & 0.053 & 0.087 & 0.044 & 0.132 & 0.29 & 0.055 & 0.125 & 0.047 & 0.217 & 0.002 \\
\hline Diourbel & 0.34 & 0.539 & 0.308 & 0.097 & 0.21 & 0.168 & 0.105 & 0.075 & 0.133 & 0.046 & 0.099 & 0.069 \\
\hline Saint-Louis & 0.37 & 0.494 & 0.302 & 0.079 & 0.218 & 0.182 & 0.109 & 0.061 & 0.117 & 0.035 & 0.147 & 0.053 \\
\hline Tamabacounda & 0.71 & 0.791 & 0.535 & 0.068 & 0.219 & 0.167 & 0.081 & 0.061 & 0.114 & 0.05 & 0.163 & 0.076 \\
\hline Thies & 0.28 & 0.386 & 0.2 & 0.087 & 0.225 & 0.102 & 0.14 & 0.08 & 0.143 & 0.039 & 0.153 & 0.032 \\
\hline Louga & 0.46 & 0.532 & 0.311 & 0.1 & 0.229 & 0.177 & 0.097 & 0.076 & 0.13 & 0.034 & 0.124 & 0.034 \\
\hline Fatick & 0.53 & 0.604 & 0.353 & 0.049 & 0.234 & 0.137 & 0.105 & 0.073 & 0.128 & 0.04 & 0.151 & 0.084 \\
\hline Kolda & 0.75 & 0.831 & 0.579 & 0.065 & 0.226 & 0.184 & 0.056 & 0.047 & 0.11 & 0.043 & 0.159 & 0.11 \\
\hline Matam & 0.52 & 0.69 & 0.428 & 0.073 & 0.196 & 0.162 & 0.123 & 0.078 & 0.124 & 0.046 & 0.162 & 0.035 \\
\hline Kaffrine & 0.83 & 0.868 & 0.596 & 0.093 & 0.235 & 0.195 & 0.085 & 0.062 & 0.111 & 0.045 & 0.151 & 0.024 \\
\hline Kedougou & 0.72 & 0.84 & 0.525 & 0.058 & 0.214 & 0.202 & 0.084 & 0.055 & 0.121 & 0.044 & 0.171 & 0.05 \\
\hline Total & 0.5 & 0.614 & 0.377 & 0.07 & 0.218 & 0.178 & 0.092 & 0.065 & 0.123 & 0.044 & 0.144 & 0.067 \\
\hline
\end{tabular}

Source: DHS-7. Senegal. Calculated and elaborated by the author. 

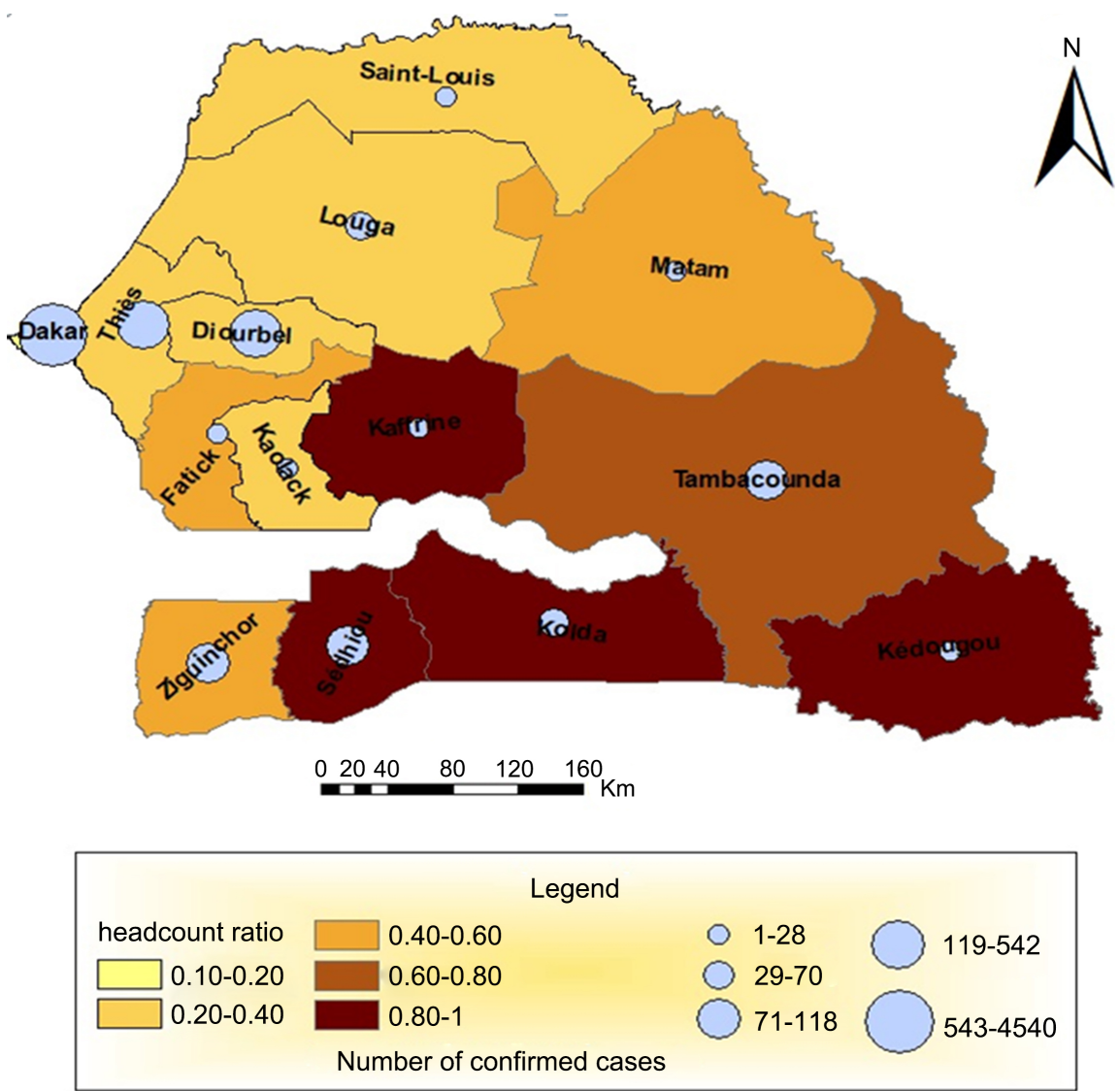

Source: DHS-7 Senegal, 2017. MSAS Senegal, 2020

Figure 6. Senegalese region: Number of people who are vulnerable and are at high risk from COVID-19 with COVID-19 cases (the map depicts confirmed infections as of June 22th. 2020).

shows that there are more infected cases in less risky regions such as Dakar or Diourbel. As explained above, the main risk factors in this area are promiscuity and sanitation. The appearance of the virus in the most vulnerable regions could imply more widespread contagiousness.

\section{Discussion and Conclusion}

The research objective of this paper was a continuation of the work of (Alkire et al., 2020) and (Tavares \& Betti, 2020) and the contextualization of their results in Senegal. To this end, we designed a multidimensional poverty index, based on the AF method, to identify people vulnerable to COVID-19 and risk factors.

Using data from the Senegalese DHS, the findings show that the proportion of individuals vulnerable to COVID-19 is higher than the poverty rate (defined according to the wealth index). However, vulnerable people are also found in regions that are more affected by poverty. This also confirms the thesis established by (Diwakar, 2020) on poverty and lack of capacity to cope with a pandemic in developing countries.

To cope with the disease, Senegal has put a particular emphasis on hygienic 
measures such as handwashing with soap and water. (Alkire et al., 2020) identified water deprivation as an important risk factor. The findings of this paper suggest instead that the most important risk factors are related to deprivation in the housing environment. The importance of "Housing", "sanitation", etc. also shows the challenges for countries such as Senegal to opt for the lockdown to limit the spread of the virus. Furthermore, in the context of the fight against COVID-19, it is easier to strengthen the capacity to have good hygiene by providing easy access to drinking water. But the living environment requires more structural reforms over the long term to strengthen the resilience of populations to certain emerging diseases that require containment to curb their spread. Moreover, in the Senegalese context, the living environment is the most relevant determinant of well-being (Sarr \& Ba, 2017).

As of June $20^{\text {th }} 2020$, the number of cases infected with COVID-19 in Senegal continues to increase. The results of this article show that the epidemic's epicenter (Dakar and Diourbel) are not the regions where the most vulnerable populations live. It is therefore important, by way of recommendation, to proceed with short- and long-term control policies. In the short term, deprivations in hygiene indicators (water, toilets) and nutrition can be corrected by distributing emergency aid according to the regions where the most vulnerable populations are located. For example, in a region such as Ziguinchor, access to drinking water should be reinforced. The distribution of disinfectant for toilets could also be an appropriate means of combating the spread of the virus. In the long term, this research results have shown that certain deprivations are important risk factors for COVID-19 contamination. They prevent individuals from following sanitary measures to protect themselves against the virus. Thus, to improve public health in the long term and at the same time reduce poverty, it is necessary to strengthen: access to electricity, improved housing conditions, better urbanization to reduce promiscuity in homes, and reduction of air pollution by substituting the use of fuels such as coal with other products such as gas in the kitchen, among others. For areas that are heavily affected by the disease such as Dakar, the results of this study showed that the main causes are promiscuity or, more broadly, the difficulty of observing physical distance. To this end, the Dakar region, like that of Thiès or Diourbel, needs to define a new housing policy after COVID-19 accompanied by measures to improve the living environment. This policy is as necessary for the prevention of emerging diseases as for the improvement of social welfare or the reduction of poverty in the field of housing and health.

The results of this paper do not determine the impact of COVID-19 on poverty. To address the implications of this issue, we would have to wait for the availability of real data of 2020 on the living conditions of households. Also deprivation in health capability informs on the degree of vulnerability of people to emerging diseases and the A-F method can help public decision making to take preventive measures and also to fight against poverty which remains a factor of transmission of infectious diseases. 


\section{Conflicts of Interest}

The author declares no conflicts of interest regarding the publication of this paper.

\section{References}

Abramowitz, S. A., McLean, K. E., McKune, S. L., Bardosh, K. L., Fallah, M., Monger, J., Tehoungue, K., \& Omidian, P. A. (2015). Correction: Community-Centered Responses to Ebola in Urban Liberia: The View from Below. PLOS Neglected Tropical Diseases, 9, e0003767. https://doi.org/10.1371/journal.pntd.0003767

Alkire, S., Dirksen, J., Nogales, R., \& Oldiges, C. (2020). Multidimensional Poverty and COVID-19 Risk Factors: A Rapid Overview of Interlinked Deprivations across 5.7 Billion People. OPHI Briefing 53.

Alkire, S., \& Foster, J. (2007). Counting and Multidimensional Poverty Measurement.

Alkire, S., \& Foster, J. (2011). Counting and Multidimensional Poverty Measurement. Journal of Public Economics, 95, 476-487.

https://doi.org/10.1016/j.jpubeco.2010.11.006

Alkire, S., Roche, J. M., Ballon, P., Foster, J., Santos, M. E., \& Seth, S. (2015). Multidimensional Poverty Measurement and Analysis. Oxford: Oxford UniversityPress. https://doi.org/10.1093/acprof:oso/9780199689491.001.0001

ANSD (2013). Rapport définitif de la deuxième Enquête de Suivi de la Pauvreté au Sénégal (ESPS II). Agence Nationale de la Statistique et de la Démographie (ANSD). http://anads.ansd.sn/index.php/catalog/17/download/349

ANSD (2015). Enquête à l'Ecoute du Sénégal 2014, L2S. Agence Nationale de la Statistique et de la Démographie (ANSD).

ANSD, \& ICF (2018). Sénégal: Enquête Démographique et de Santé Continue (EDSContinue 2017).

Bourguignon, F., \& Chakravarty, S. R. (2008). Multidimensional Poverty Orderings: Theory and Applications. In Poverty, Social Exclusion and Stochastic Dominance (pp. 143-166). Berlin: Springer. https://doi.org/10.1093/acprof:oso/9780199239115.003.0019

Bucchianeri, G. W. (2010). Is SARS a Poor Man's Disease? Socioeconomic Status and Risk Factors for SARS Transmission. Forum for Health Economics \& Policy, 13, Article 10. https://doi.org/10.2202/1558-9544.1209

Buheji, M., da Costa Cunha, K., Beka, G., Mavric, B., de Souza, Y. L., da Costa Silva, S. S., Hanafi, M., \& Yein, T. C. (2020). The Extent of COVID-19 Pandemic Socio-Economic Impact on Global Poverty. A Global Integrative Multidisciplinary Review. American Journal of Economics, 10, 213-224.

Chakraborty, N. M., Fry, K., Behl, R., \& Longfield, K. (2016). Simplified Asset Indices to Measure Wealth and Equity in Health Programs: A Reliability and Validity Analysis Using Survey Data from 16 Countries. Global Health: Science and Practice, 4, 141-154. https://doi.org/10.9745/GHSP-D-15-00384

Cheli, B., \& Lemmi, A. (1995). A "Totally" Fuzzy and Relative Approach to the Multidimensional Analysis of Poverty. Economic Notes by Monte Dei Pashi Siena, 24, 115134.

Chen, W., \& Chang, Z. (2019). Recognition Method of Multidimensional Poverty Based on Mahalanobis-Taguchi System. Open Journal of Social Sciences, 7, 161-174. https://doi.org/10.4236/jss.2019.78012

Chiappero Martinetti, E. (2000). A Multidimensional Assessment of Well-Being Based on 
Sen's Functioning Approach. Rivista Internazionale Di Scienze Sociali, 108, 207-239.

Croft, T. N., Marshall, A. M., Allen, C. K., Arnold, F., Assaf, S., \& Balian, S. (2018). Guide to DHS Statistics. Rockville, MD: ICF.

Diwakar, D. M. (2020). From Pandemics to Poverty. Hotspots of Vulnerability in Times of Crisis. Emerging Analysis and Ideas.

Duclos, J.-Y., Sahn, D. E., \& Younger, S. D. (2006). Robust Multidimensional Poverty Comparisons. The Economic Journal, 116, 943-968.

https://doi.org/10.1111/j.1468-0297.2006.01118.x

Foster, J., Greer, J., \& Thorbecke, E. (1984). A Class of Decomposable Poverty Measures. Econometrica, 53, 761-766. https://doi.org/10.2307/1913475

Krishnakumar, J. (2014). Quantitative Methods for the Capability Approach. In Social and Cultural Development of Human Resources (pp. 1-30). Paris: Eolss Publishers.

Krishnakumar, J., \& Ballon, P. (2008). Estimating Basic Capabilities: A Structural Equation Model Applied to Bolivia. World Development, 36, 992-1010.

https://doi.org/10.1016/j.worlddev.2007.10.006

Maggino, F., \& Zumbo, B. D. (2012). Measuring the Quality of Life and the Construction of Social Indicators. In Handbook of Social Indicators and Quality of Life Research (pp. 201-238). Berlin: Springer. https://doi.org/10.1007/978-94-007-2421-1 10 http://link.springer.com/chapter/10.1007/978-94-007-2421-1 10

Nardo, M., Saisana, M., Saltelli, A., Tarantola, S., Hoffman, A., \& Giovannini, E. (2005). Handbook on Constructing Composite Indicators.

http://www.oecd-ilibrary.org/economics/handbook-on-constructing-composite-indicat ors 533411815016

OPHI (2019). Global MPI Country Briefing 2019: Senegal (Sub-Saharan Africa). Oxford: Oxford Department of International Development; Queen Elizabeth House, University of Oxford.

Rothan, H. A., \& Byrareddy, S. N. (2020). The Epidemiology and Pathogenesis of Coronavirus Disease (COVID-19) Outbreak. Journal of Autoimmunity, 109, Article ID: 102433. https://doi.org/10.1016/j.jaut.2020.102433

Sarr, F., \& Ba, M. (2017). The Capability Approach and Evaluation of the Well-Being in Senegal: An Operationalization with the Structural Equations Models. Modern Economy, 8, 90-110. https://doi.org/10.4236/me.2017.81007

Sen, A. K. (1976). Poverty: An Ordinal Approach to Measurement. Econometrica, 44, 219-231. https://doi.org/10.2307/1912718

Sen, A. K. (1980). Equality of What. In McMurrin's Tanner Lectures on Human Values (Vol. 1). Cambridge: Cambridge University Press. http://tannerlectures.utah.edu/ documents/a-to-z/s/sen80.pdf

Sen, A. K. (1985). Commodities and Capabilities. Amsterdam: North-Holland.

Sen, A. K. (2000). Un nouveau Modèle Economique, Développement, Justice; Liberté. ODILE JACOB.

Sen, A. K. (2009). The Idea of Justice. Cambridge, MA: Harvard University Press. https://doi.org/10.2307/j.ctvjnrv7n

Tavares, F. F., \& Betti, G. (2020). Vulnerability, Poverty, and COVID-19: Risk Factors and Deprivations in Brazil. https://www.researchgate.net/publication/340660228

WHO (2018a). Household Air Pollution and Health. Geneva: World Health Organization. https://www.who.int/news-room/fact-sheets/detail/household-air-pollution-and-health

WHO (2018b). Water Sanitation Hygiene. Geneva! World Health Organization. 
https://www.researchgate.net/community/COVID-19

WHO (2019). Drinking-Water Key Facts. Geneva: World Health Organization. https://www.who.int/news-room/fact-sheets/detail/drinking-water

WHO (2020). Coronavirus Disease 2019 (COVID-19): Situation Report 72. Geneva!: World Health Organization. 


\section{Appendix}

Table A1. Descriptive statistical.

\begin{tabular}{cccccc}
\hline Variable & $\begin{array}{c}\text { Number of } \\
\text { observations }\end{array}$ & Minimum & Maximum & Means & $\begin{array}{c}\text { Standard } \\
\text { deviation }\end{array}$ \\
\hline Education & 74,444 & 0.0000 & 1.0000 & 0.3852 & 0.4866 \\
Electricity & 74,444 & 0.0000 & 1.0000 & 0.4683 & 0.4990 \\
Housing & 74,444 & 0.0000 & 1.0000 & 0.4589 & 0.4983 \\
Cooking fuel & 74,444 & 0.0000 & 1.0000 & 0.8453 & 0.3616 \\
Water & 74,444 & 0.0000 & 1.0000 & 0.3270 & 0.4691 \\
Sanitation & 74,444 & 0.0000 & 1.0000 & 0.5157 & 0.4998 \\
Nutrition & 74,444 & 0.0000 & 1.0000 & 0.3826 & 0.4860 \\
Promiscuity & 74,444 & 0.0000 & 1.0000 & 0.3137 & 0.4640 \\
Dependence ratio & 74,444 & 0.0000 & 1.0000 & 0.2865 & 0.4521 \\
\hline
\end{tabular}

Source: DHS-7. Senegal. Calculated and elaborated by the author.

Table A2. Distribution of deprivation rates for each indicator.

\begin{tabular}{ccc}
\hline Dimensions & Indicators & $\%$ population deprived \\
\hline Education & Education & $38.52 \%$ \\
Staying at home & Electricity & $46.82 \%$ \\
Physical distance & Housing & $45.89 \%$ \\
& Promiscuity & $31.37 \%$ \\
Recovery capacity & Dependence ratio & $28.65 \%$ \\
& Cooking fuel & $84.52 \%$ \\
Hygiene & Nutrition & $38.25 \%$ \\
& Sanitation & $51.57 \%$ \\
\hline
\end{tabular}

Source: DHS-7. Senegal. Calculated and elaborated by the author.

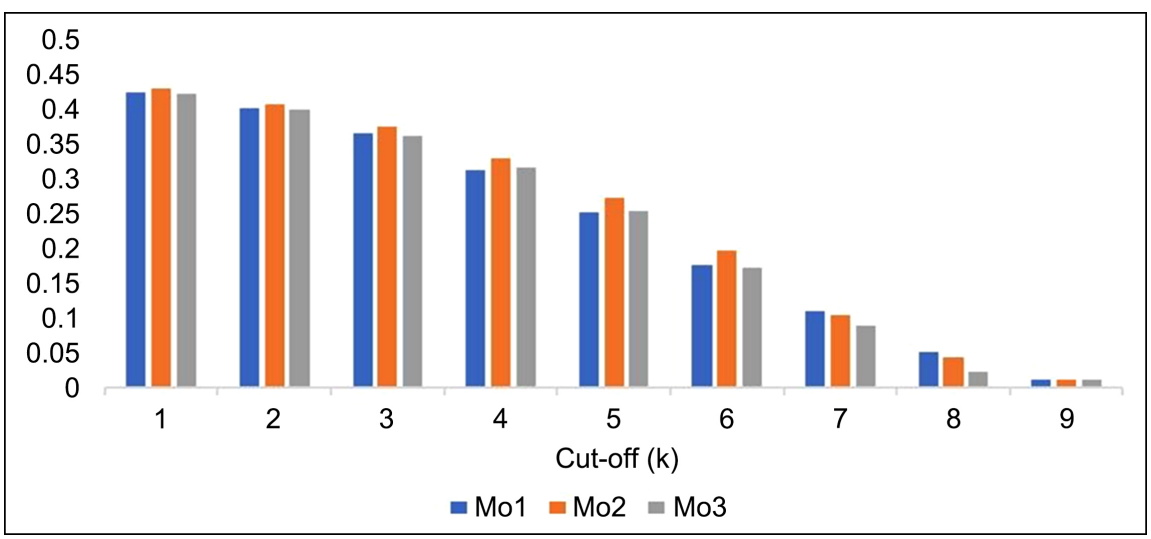

Figure A1. Headcount ratios for different cut-off and weighting structures: equal weights (H1); PCA weights (H2) and subjectively determined weights (H3). Source: DHS-7. Senegal. Calculated and elaborated by the author. 
Table A3. Rotated factor loadings.

\begin{tabular}{cccccc}
\hline \multirow{2}{*}{ Indicators } & \multicolumn{2}{c}{ Axis_1 } & \multicolumn{2}{c}{ Axis_2 } & \multirow{2}{*}{ Weight } \\
\cline { 2 - 5 } & Corr. & $\%($ Tot. \%) & Corr. & $\%($ Tot. \%) & \\
\hline Electricity & 0.78066 & $61 \%(61 \%)$ & 0.13597 & $2 \%(63 \%)$ & 0.1815 \\
Housing & 0.72575 & $53 \%(53 \%)$ & 0.06679 & $0 \%(53 \%)$ & 0.1569 \\
Sanitation & 0.63577 & $40 \%(40 \%)$ & 0.12714 & $2 \%(42 \%)$ & 0.1204 \\
Water & 0.55343 & $31 \%(31 \%)$ & -0.07659 & $1 \%(31 \%)$ & 0.0912 \\
Education & 0.52202 & $27 \%(27 \%)$ & 0.16034 & $3 \%(30 \%)$ & 0.081 \\
Cooking-fuel & 0.5121 & $26 \%(26 \%)$ & 0.24313 & $6 \%(32 \%)$ & 0.0781 \\
Promiscuity & -0.08191 & $1 \%(1 \%)$ & 0.77299 & $60 \%(60 \%)$ & 0.1365 \\
Dependence ratio & 0.13885 & $2 \%(2 \%)$ & 0.65896 & $43 \%(45 \%)$ & 0.0992 \\
Nutrition & 0.22685 & $5 \%(5 \%)$ & 0.48893 & $24 \%(29 \%)$ & 0.0546 \\
Total variance explained & 2.45883 & $27 \%(27 \%)$ & 1.40058 & $16 \%(43 \%)$ & 1 \\
\hline
\end{tabular}

Source: DHS-7. Senegal. Calculated and elaborated by the author from TANAGRA (2014).

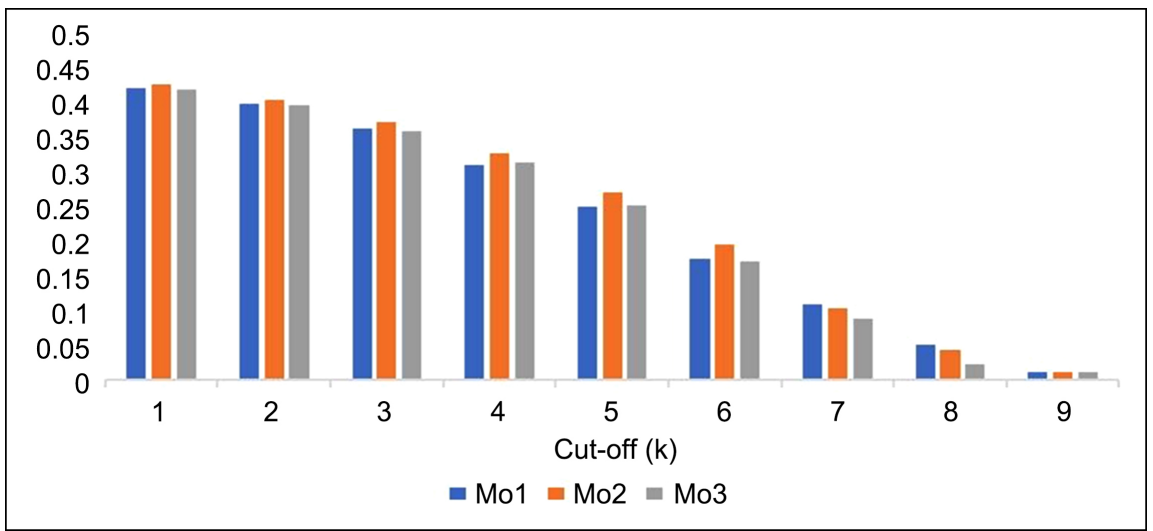

Figure A2. Adjusted headcount ratios for different cut-off and weighting structures: equal weights (H1); PCA weights (H2) and subjectively determined weights (H3). Source: DHS-7. Senegal. Calculated and elaborated by the author. 